\title{
Influence of oxygen partial pressure and salinity on the community composition of ammonia-oxidizing bacteria in the Schelde estuary
}

\author{
Annette Bollmann*, Hendrikus J. Laanbroek
}

NIOO-KNAW Centre for Limnology, Department of Microbial Ecology, Rijksstraatweg 6, 3631 AC Nieuwersluis, The Netherlands

\begin{abstract}
The influence of environmental factors on the community structure of ammoniaoxidizing bacteria (AOB) was investigated in the Schelde estuary. Simultaneously with the increase of oxygen and salinity, a shift of the dominant AOB was observed. Molecular analysis based on $16 \mathrm{~S}$ rRNA genes showed that the freshwater area was dominated by Nitrosomonas-like sequences which were closely related to $N$. ureae and $N$. oligotropha. In the brackish area, sequences of a novel group of Nitrosomonas-like bacteria and relatives of N. marina and N. aestuarii were found. Batch and continuous culture experiments were used to investigate the reason behind the community shift. Batch incubations showed a positive influence of the natural water from the Schelde estuary on ammonia oxidation, compared to mineral medium. The ammonia oxidation rates of the AOB originating from the brackish water were higher in the absence of salt. Water from the freshwater part was incubated in continuous cultures under 3 different conditions of salinity and oxygen partial pressure. Under all conditions, ammonia consumption in the continuous cultures started at once. Molecular analysis resulted in a clear phylogenetic difference between the absence and presence of salt, indicating that salt is the factor which causes the community shift of the AOB in the Schelde estuary.
\end{abstract}

KEY WORDS: Nitrification · Ammonia oxidation · Oxygen partial pressure - Salinity · DGGE · Continuous culture $\cdot$ Estuaries $\cdot$ Freshwater

Resale or republication not permitted without written consent of the publisher

\section{INTRODUCTION}

Nitrification, the oxidation of ammonia to nitrate, is an environmentally important process. This process, which takes place in different environments such as soils, sediments, and the water column, is controlled by such abiotic factors as oxygen partial pressure and salinity. Oxygen partial pressure has a direct influence on the ammonia oxidation, because oxygen is required to oxidize ammonia to hydroxylamine through the enzyme ammonia monooxygenase (Wood 1987). Oxygen is also the terminal electron acceptor, but can be replaced under oxygen-limited conditions by nitrite,

*Present address. Department of Microbial Ecology, Institute of Biological Science, University of Aarhus, Ny Munkegade Bld. 540, 8000 Aarhus C, Denmark.

E-mail: annette.bollmann@biology.au.dk which is reduced to $\mathrm{NO}, \mathrm{N}_{2} \mathrm{O}$, and $\mathrm{N}_{2}$ (Poth \& Focht 1985, Poth 1986, Anderson et al. 1993). Studies have shown that different oxygen conditions in soils and sediments change the activity and the affinity for $\mathrm{O}_{2}$ of the AOB present (Bodelier et al. 1996) but have no effect on the community structure (Kowalchuk at al. 1998). Salinity also influences the life strategies of bacteria. Bacteria are able to survive in environments with high salinity by keeping their cytoplasm at the same osmotic level as that of the surrounding environment (Oren 1999). AOB have been found in marine and moderately saline environments up to salt concentrations of $100 \mathrm{~g} \mathrm{l}^{-1}$ (Stephen et al. 1996, Bano \& Hollibaugh 2000, Ward et al. 2000). At higher salt concentrations ammonia oxidation is not observed because of energy constraints for halophilism (Oren 1999). Salinity has an influence on the nitrifying activity (Somville 1984, Rysgaard et al. 1999) as well as on the commu- 
nity structure of AOB (Pommerening-Röser et al. 1996, Stephen et al. 1998, Purkhold et al. 2000). These observations indicate that oxygen and salinity affect $\mathrm{AOB}$ by different mechanisms. In the Schelde estuary both factors, the oxygen partial pressure and the salinity, increase simultaneously (Soetaert \& Herman 1995). The molecular analysis of the AOB community showed a shift of the dominant populations parallel with the increase of the oxygen partial pressure and the salinity (de Bie et al. 2001). This observation raises the question whether the shift was driven by the increase in oxygen partial pressure or salinity. Therefore we will present a number of batch and continuous culture experiments investigating the influence of oxygen and salinity on the activity and community composition of the AOB in the Schelde estuary.

\section{MATERIALS AND METHODS}

Site description and sampling. The Schelde estuary drains an area of northern France, Belgium and the Netherlands (for a more detailed description see Soetaert \& Herman 1995 and de Bie et al. 2001). Along the salinity and oxygen gradient, surface water samples from the upper $50 \mathrm{~cm}$ were taken from the same sampling points as used by de Bie et al. (2001) on board the RV 'Luctor' on August 2, 1999, and November 2, 1999. These samples were assumed to give a good representation of the microbial community in the whole water column, because the vertical stratification in this system is minimal (Wollast 1988). Two sampling points at the extremes of the sampled gradient were chosen for more detailed experiments, one in the freshwater area near the village Temse $\left(51^{\circ} 24^{\prime} \mathrm{N}, 4^{\circ} 12^{\prime} \mathrm{E}\right)$ (W1) and one in the brackish area near Bath $\left(51^{\circ} 8^{\prime} \mathrm{N}, 4^{\circ} 13^{\prime} \mathrm{E}\right)$ (W8). The samples were transferred to screw cap bottles or PVC tanks, transported to the lab and stored at $4^{\circ} \mathrm{C}$. Salinity and oxygen concentration were determined aboard with a conductivity/temperature/depth (CTD) system equipped with a polarographic oxygen sensor (TRISHYDRO H2O, Lokeren).

Media. Different media were used for the experiments: (1) Mineral medium contained $10 \mathrm{mM} \mathrm{NaCl}$, $1 \mathrm{mM} \mathrm{KCl}, 0.2 \mathrm{mM} \mathrm{MgSO}_{4} \cdot 7 \mathrm{H}_{2} \mathrm{O}, 1 \mathrm{mM} \mathrm{CaCl} 2 \cdot 2 \mathrm{H}_{2} \mathrm{O}$, $0.4 \mathrm{mM} \mathrm{KH}_{2} \mathrm{PO}_{4}$ and $1 \mathrm{ml} \mathrm{l}^{-1}$ trace element solution (Verhagen \& Laanbroek 1991) in distilled water. (2) Water from the 2 sampling points Temse and Bath in the Schelde estuary was used as basis of the medium. The water was filtered twice, first with a $0.45 \mu \mathrm{m}$ membrane filter, to remove the aggregates and then with a $0.2 \mu \mathrm{m}$ filter to sterilize the water. The filtration was done within $2 \mathrm{wk}$ after sampling and the filtered water was stored at room temperature. No growth was observed during storage. The water was in some cases supplemented with the same mineral salts as used in the mineral medium and in case of the freshwater with $\mathrm{NaCl}$ to a final salt concentration of $16.3 \mathrm{~g} \mathrm{l}^{-1}$ of $\mathrm{Cl}^{-}$.

Batch experiments. To investigate the influence of different media on the ammonia oxidation, river water samples were taken in August 1999. We used mineral medium or water from the sampling points Temse and Bath as basic media, all supplemented with $1 \mathrm{mM}$ ammonium and 5 mM HEPES (pH 7.8) for buffering. Water from Temse and Bath itself was used as inoculum and diluted 1:10 while inoculating the samples. These dilutions were incubated on a shaker at $120 \mathrm{rpm}$ and $25^{\circ} \mathrm{C}$. The growth rate of the AOB was determined by measuring the changes in nitrite and nitrate concentrations and calculated via ln transformation of the nitrite (plus nitrate) contents (Belser \& Schmidt 1980).

Continuous culture experiments. The continuous culture enrichments were carried out in Biostat $\mathrm{M}$ fermenters (B. Braun, Melsungen) as described by Verhagen \& Laanbroek (1991). All cultures of approximately $1 \mathrm{l}$ were kept at a temperature of $25^{\circ} \mathrm{C}$ and a stirrer speed of $200 \mathrm{rpm}$. The $\mathrm{pH}$ was adjusted continuously to $7.5 \pm 0.2$ by adding $0.5 \% \mathrm{Na}_{2} \mathrm{CO}_{3}$ or $0.1 \mathrm{M} \mathrm{HCl}$. At the start the continuous culture vessels were filled completely with water from the freshwater sampling point Temse (W1) sampled on November 2, 1999. The cultures were kept for $24 \mathrm{~h}$ under high oxygen partial pressure $\left(20 \% \mathrm{O}_{2}\right)$ and without medium addition. Then the selective conditions were applied: Continuous Culture 1 (Ch1): low oxygen $\left(0.6-1 \% \mathrm{O}_{2}\right)$ and low salt (medium: water from W1); Continuous Culture 2 (Ch2): high oxygen $\left(20 \% \mathrm{O}_{2}\right)$ and low salt (medium: water from W1); and Continuous Culture 3 (Ch3): high oxygen $\left(20 \% \mathrm{O}_{2}\right)$ and high salt (medium: water from Bath [W8]). The medium was water from either one of the 2 sampling points supplemented with ammonium and was added at a dilution rate of $0.01 \mathrm{~h}^{-1}$. The reduced oxygen partial pressure was controlled by a gas flow ratio controller (B. Braun, type B210) consisting of a nitrogen and an air mass flow controller coupled to an oxygen electrode (Ingold). When the ammonium was consumed completely, the ammonium concentration in the reservoir was increased to obtain more biomass in the cultures. The chemostats were sampled daily to determine the ammonium, nitrite and nitrate concentrations, and every fourth day, i.e. after every volume change, samples were taken for molecular analysis.

Chemical analysis. The samples were analyzed immediately or stored at $-20^{\circ} \mathrm{C}$. Ammonium (Kandeler \& Gerber 1988) and nitrite (Keeney \& Nelson 1982) were determined colorimetrically. Nitrate was measured with high-pressure liquid chromatography (HPLC) (according to Bollmann \& Laanbroek 2001).

Molecular analysis. For the molecular analysis, $20 \mathrm{ml}$ of chemostat culture liquid or $10 \mathrm{ml}$ of the batch cul- 
tures were filtered through a $0.2 \mu \mathrm{m}$ membrane filter NC20 (Schleicher \& Schuell). These filters were cut into 2 parts, put into $2 \mathrm{ml}$ screw-cap tubes and stored until further analysis at $-80^{\circ} \mathrm{C}$. DNA was extracted as described by Bollmann \& Laanbroek (2001). The DNA was amplified with the CTO189F-GC/CTO654-R primer set using a Taq polymerase (Kowalchuk et al. 1997, de Bie et al. 2001) with the following modifications: we used $1.75 \mathrm{mM} \mathrm{Mg}^{2+}$ and 40 cycles of PCR. Denaturing Gradient Gel Electrophoresis (DGGE) was performed as described by Kowalchuk et al. (1997) with modifications from de Bie et al. (2001). The sequencing of the DGGE bands and the data analysis were carried out as described by de Bie et al. (2001). For that purpose the center of the band was cut out and incubated over night in $50 \mu \mathrm{TE}$ at $4^{\circ} \mathrm{C}$. This solution was used for PCR with the CTO primer set. Afterwards the PCR products were reanalyzed on DGGE to confirm the recovery of the excised bands and used subsequently for sequencing without further purification. Sequencing was done with internal Cy5 labeled primers 357F and 518R (Muyzer et al. 1993) and a cycle sequence kit (Amersham Pharmacia Biotech) and analyzed on an ALF Express II (Amersham Pharmacia Biotech) according to the manufacturer's instructions.

Sequences were processed with ALF Express Sequence Analysis Software. Alignment of the sequences was done with the Dedicated Comparative Sequence Editor program (DCSE) (de Rijk \& de Wachter 1993) including sequences from the small subunit (ssu) rRNA database (Antwerp, Belgium) (van de Peer et al. 1997). Distance analysis of 402 nucleotide positions

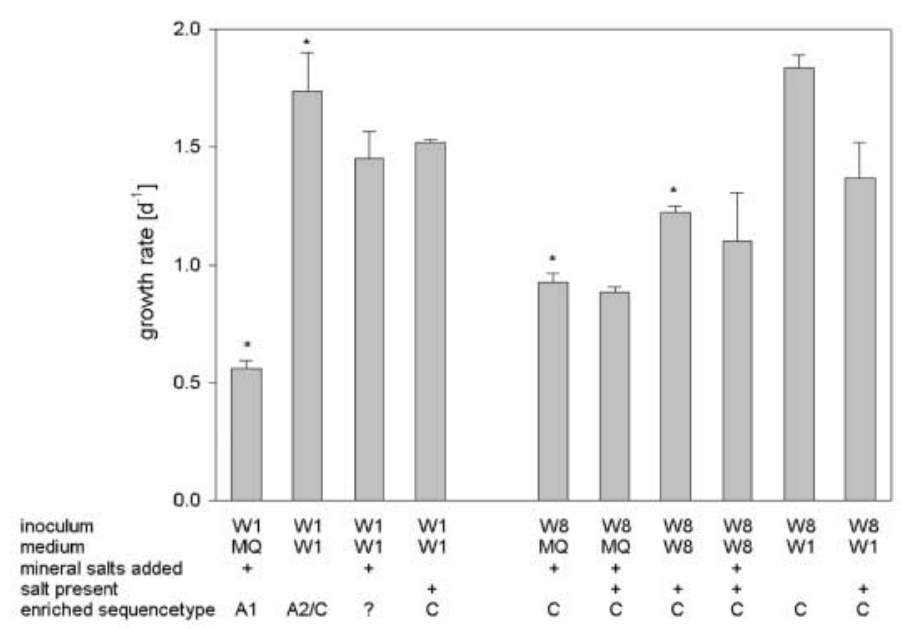

Fig. 1. Growth rates of the ammonia-oxidizing bacteria present in the Schelde estuary determined in different media ( ${ }^{\star}$ mean $\pm \mathrm{SD}, \mathrm{n}=4$; rest: mean \pm range, $\mathrm{n}=2$ ). The enriched sequence types correspond to the sequence types as defined in the phylogenetic tree (Fig. 2). W1: water from the freshwater sampling point Temse; W8: water from the brackish water sampling point Bath; MQ: distilled water
(Escherichia coli numbering: 206-608) of the alignment was performed with Treecon version $1.3 \mathrm{~b}$ software (van de Peer \& de Wachter 1994) using Jukes \& Cantor's (1969) correction. Gaps were not taken into account in the analysis. The bootstrap analysis was based on 100 replicates. Additionally, maximum parsimony and distance analyses of the sequences were performed with the PHYLIP version 3.5c (Felsenstein 1993). All methods showed the same grouping in the phylogenetic tree. The sequences determined in this study have been deposited in the EMBL database under the accession numbers AJ316209 to AJ316216.

In addition, we used a nested PCR-DGGE approach to profile the population shifts in the continuous cultures as described for methanotrophic bacteria (Wise et al. 1999). For that purpose, 1:1000 diluted CTO-PCR products were used as template for a PCR with the primers F357GC and R518 using a Taq polymerase, and the PCR products were analyzed by DGGE (Muyzer et al. 1993) with modifications from Zwart et al. (1998). To compare the DGGE profiles of the continuous cultures with the sequences obtained from the cut-out bands, we also amplified the cut-out bands with the primers F357GC and R518 and analyzed them by DGGE. For some unknown reason, some of the bands appeared in a reproducible pattern of double bands.

\section{RESULTS}

We used batch and continuous culture experiments to investigate the factor causing the population shift of AOB in the river Schelde estuary. In August 1999 we sampled water at the same locations as de Bie et al. (2001) and observed the same population shift of the AOB by using molecular methods (DNA isolation, PCR and DGGE) (results not shown). For further experiments, water from the sampling points Temse (freshwater, W1) with low oxygen partial pressure and low salinity and from Bath (brackish water, W8) with high oxygen partial pressure and high salinity were used (Table 1).

Table 1. Ammonium, nitrite, nitrate, $\mathrm{pH}$, oxygen partial pressure $\left(\mathrm{pO}_{2}\right)$ and salinity in the water samples at the 2 sampling stations Temse and Bath on August 2, 1999, and November 2, 1999

\begin{tabular}{|lcccc|}
\hline & \multicolumn{2}{c}{ Temse (W1) } & \multicolumn{2}{c|}{ Bath (W8) } \\
& Aug 99 & Nov 99 & Aug 99 & Nov 99 \\
\hline Ammonium [mM] & 0.012 & 0.245 & 0.017 & 0.006 \\
Nitrite [mM] & 0.012 & 0.01 & 0.005 & 0.002 \\
Nitrate [mM] & 0.417 & 0.206 & 0.213 & 0.229 \\
$\mathrm{pH}$ & 7.4 & 7.4 & 7.6 & 7.6 \\
$\mathrm{pO}_{2}[\%$ air saturation] & 4.6 & 3.9 & 75.7 & 81 \\
Salinity [g l${ }^{-1}$ of $\left.\mathrm{Cl}^{-}\right]$ & 0.7 & 1.3 & 16.2 & 16.3 \\
\hline
\end{tabular}




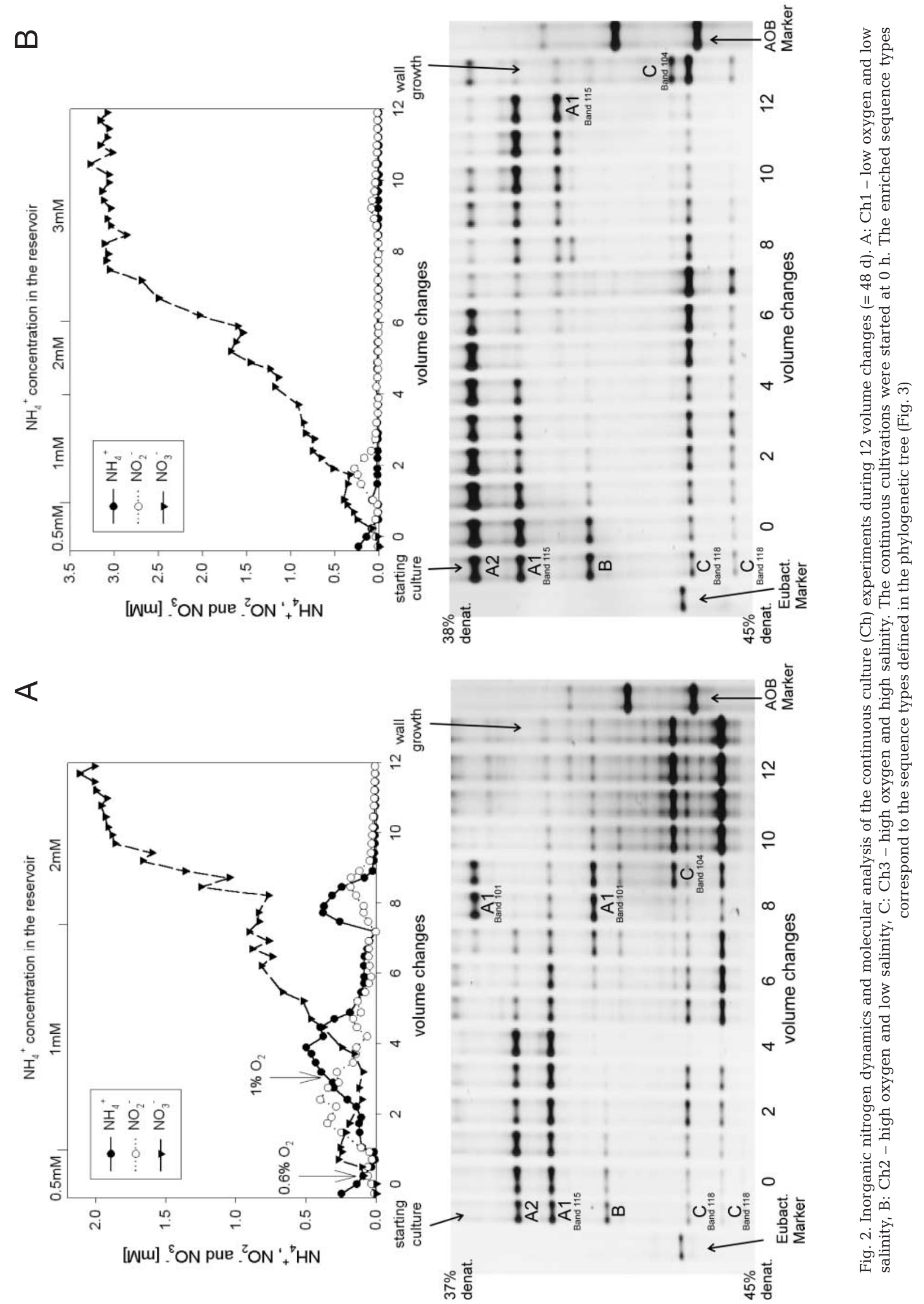




\section{Batch experiments}

The AOB from freshwater had the highest growth rates in freshwater without addition of any supplements (Fig. 1). The rates decreased dramatically when the $\mathrm{AOB}$ were incubated in mineral medium. The addition of mineral salts as used for the mineral medium of $16.3 \mathrm{~g} \mathrm{l}^{-1}$ of $\mathrm{Cl}^{-}$to the freshwater also lowered the growth rate. AOB from the brackish water showed the highest growth rates when incubated in freshwater without salt addition. The lowest growth rates were observed when incubated in mineral medium with and without salt. According to the molecular analysis, incubation with brackish water as inoculum ended always with Sequence Type C (Figs. 1 $\& 3)$. Incubations of freshwater in the presence of $16.3 \mathrm{~g} \mathrm{l}^{-1}$ of $\mathrm{Cl}^{-}$resulted also in the enrichment of Sequence Type $\mathrm{C}$ and in its absence with Sequence Types A1 or with a combination of A2 and C (Figs. 1 \& 3).

\section{Continuous culture experiment}

We used sterile filtered water from the 2 sampling points as basis for the medium, because the AOB did not become active when incubated in continuous cultures with mineral medium (results not shown). The continuous cultures were used to simulate the conditions for the AOB in the Schelde estuary. In the continuous culture Ch1, conditions in the freshwater area were simulated by applying a low oxygen partial pressure $\left(0.6 \%\right.$ to $\left.1 \% \mathrm{O}_{2}\right)$ and feeding with medium based on water from the freshwater area. To determine the driving force of the community shift, we changed first one factor by increasing the oxygen partial pressure to $20 \% \mathrm{O}_{2}$ in $\mathrm{Ch} 2$. In $\mathrm{Ch} 3$ the salinity was also increased by feeding with medium based on water from the brackish area. This continuous culture was used to simulate the conditions in the brackish area of the estuary.

In Expt Ch1 ammonium oxidation started immediately (Fig. 2A). After 1 volume change, ammonium was completely consumed, so the ammonium concentration in the reservoir was increased from 0.5 to $1 \mathrm{mM}$ ammonium. After this increase the ammonium concentration in the culture itself increased, indicating that not enough oxygen was available to oxidize the ammonium completely. To prevent a wash-out of the AOB, we increased the oxygen partial pressure in the vessel after 3 volume changes from $0.6 \% \mathrm{O}_{2}$ to $1 \% \mathrm{O}_{2}$, and ammonia was again completely oxidized. Nitrite oxidation started after 2.5 volume changes, and after approximately 9 volume changes all ammonium was completely converted to nitrate. After every volume
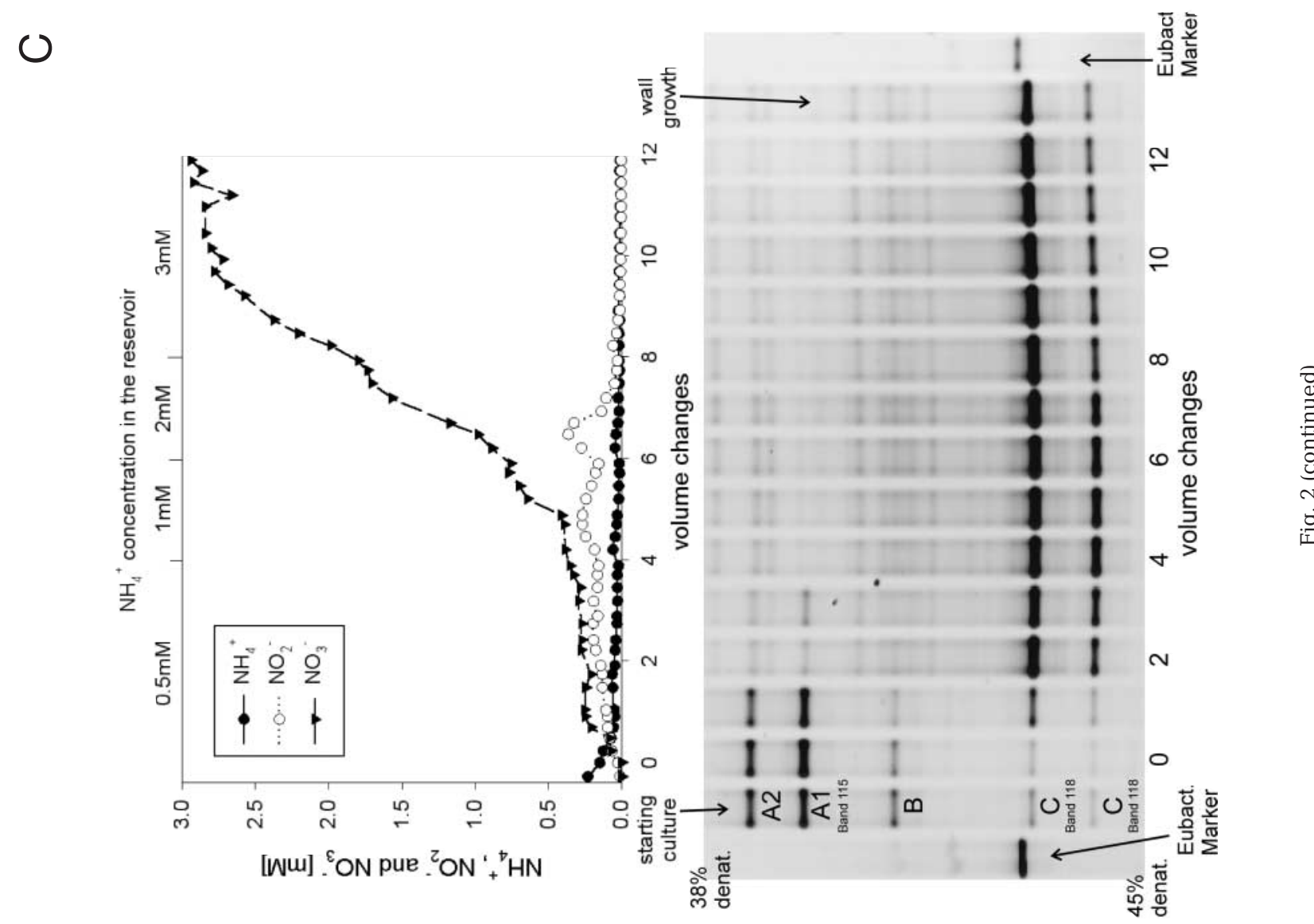
Distance 0.1

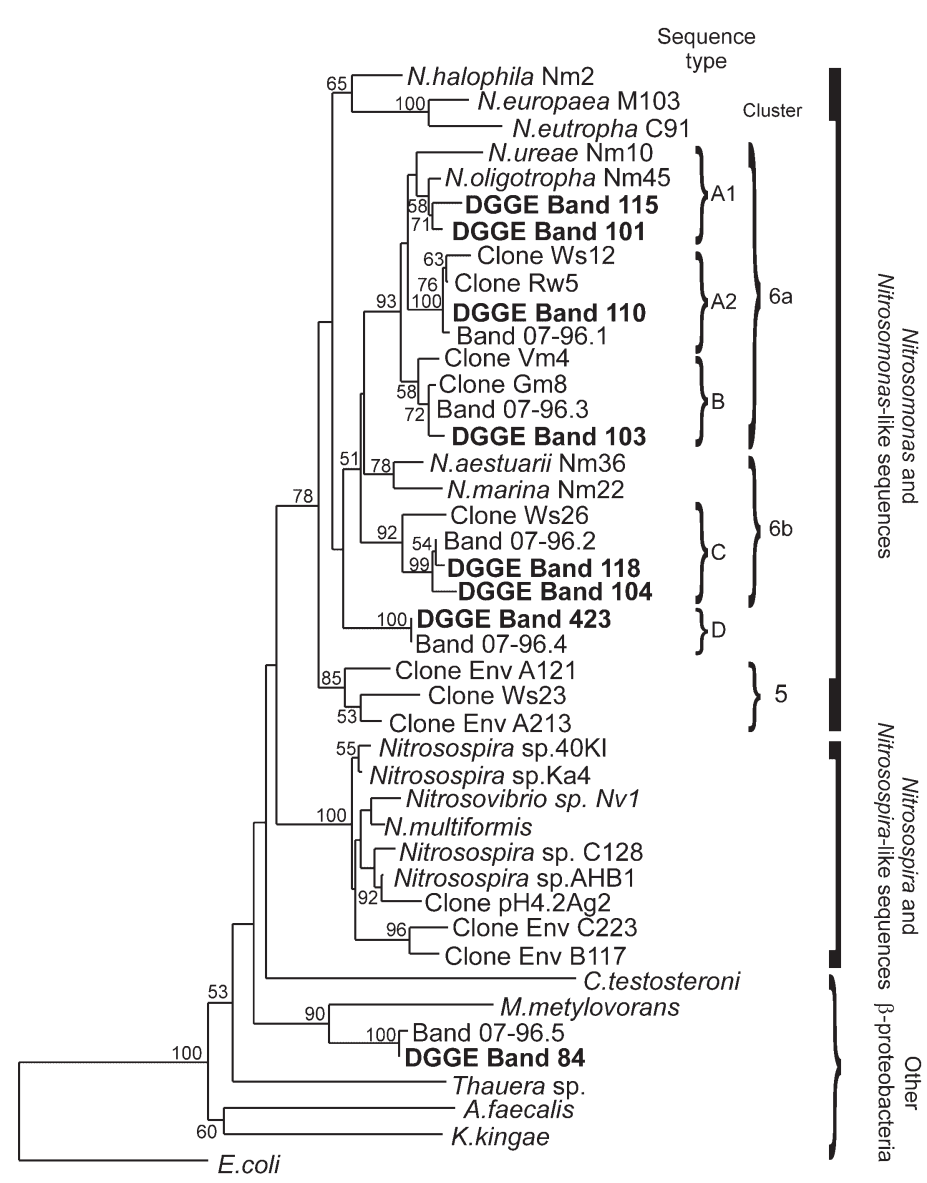

Fig. 3. Neighbor-joining phylogenetic tree of the 16S rRNA sequences from the ammonia-oxidizing bacteria enriched in continuous and batch cultures. Sequence types correspond with the sequence types presented in Figs. 1 \& 2. Codes in bold represent example sequences retrieved from excised DGGE bands from the different experiments. Bands 07-96.1 to 07-96.5 are representative sequences from de Bie et al. (2001)

change we took a sample to analyze the AOB community. In the starting culture the Sequence Types A1, A2, B, and C were present. Sequence type B disappeared after 2, A2 after 7, and A1 after 9 volume changes, respectively. At the end, only Sequence Type C was present in the culture and in the wall growth (Fig. 2A, Table 2).

In Expt Ch2 running with high oxygen partial pressure and low salinity, ammonium was completely oxidized to nitrate from the start (Fig. 2B). Only after 1 to 2 volume changes was a small nitrite peak observed. In the starting culture, all 4 sequence types were present, but Sequence Type B disappeared after only 2 volume changes. The types A1, A2, and C remained until 4 volume changes in a co-culture, but subsequently A1, $\mathrm{A} 2$ and $\mathrm{C}$ disappeared. While $\mathrm{C}$ was finally disappearing, A1 grew up again. At the end of the experiment we found the Sequence Type A1 in the culture liquid of the continuous culture and $\mathrm{C}$ in the wall growth (Fig. 2B, Table 2).

In Expt Ch3 with high oxygen partial pressure $(20 \%$ $\mathrm{O}_{2}$ ) and high salinity $\left(16.3 \mathrm{~g} \mathrm{l}^{-1}\right.$ of $\left.\mathrm{Cl}^{-}\right)$to simulate the conditions in the brackish water at Bath (W8) (Fig. 2C), ammonium was oxidized almost immediately and the ammonium concentration remained low. Nitrite was only partly oxidized to nitrate, but after 7 volume changes the ammonium was completely oxidized to nitrate. After only 2 volume changes all sequence types except $\mathrm{C}$ had disappeared. At the end of the experiment, we found the Sequence Type $C$ in the culture and at the wall of the vessel (Fig. 2C, Table 2).

In summary, we found Sequence Type $\mathrm{C}$ on the walls of all 3 vessels (Table 2). In the continuous cultures Ch1 and Ch2 (both with low salinity) the bacteria stuck tightly to the wall, whereas in Ch3 (high salinity) the bacteria were loosely bound and could be removed by rinsing them with medium. This was probably a physical effect due to electrostatic interactions, which are influenced by the salinity of the medium. The cultures themselves differed in the dominant AOB: in the continuous cultures $\mathrm{Ch} 1$ and $\mathrm{Ch} 3$, Sequence Type C

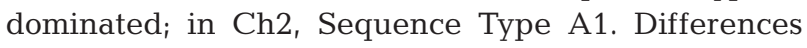
were also found in the growth-limiting substrate concentration, which were around $7 \mu \mathrm{M}$ ammonium in the cultures without salt (Ch1 and Ch2) and $12 \mu \mathrm{M}$ in the culture with salt (Table 2).

\section{DISCUSSION}

Summing up the results from the batch and continuous culture experiments, salt was the factor causing the community shift of the AOB in the Schelde estuary. Sequence Type $C$ came to the fore in all batch experiments when the $\mathrm{AOB}$ came in contact with $\mathrm{NaCl}$

Table 2. Experimental conditions, enriched sequence types and growthlimiting substrate concentrations calculated as mean $\pm \mathrm{SD}$ of the $\mathrm{NH}_{4}{ }^{+}$concentrations over the last 2 to 3 volume changes at the end of the experiment

\begin{tabular}{|c|c|c|c|}
\hline & Ch 1 & $\mathrm{Ch} 2$ & $\mathrm{Ch} 3$ \\
\hline Oxygen partial pressure [\%] & $0.6-1.0$ & 20 & 20 \\
\hline Salinity $\left[\mathrm{g} \mathrm{l}^{-1}\right.$ of $\left.\mathrm{Cl}^{-}\right]$ & 1.3 & 1.3 & 16.3 \\
\hline Enriched sequence type: culture & $\mathrm{C}$ & A1 & $\mathrm{C}$ \\
\hline wall growth & $\mathrm{C}$ & $\mathrm{C}$ & $\mathrm{C}$ \\
\hline $\begin{array}{l}\text { Growth-limiting substrate } \\
\text { concentration }\left[\mathrm{mM} \mathrm{NH}_{4}^{+}\right]\end{array}$ & $7.5 \pm 2.0$ & $6.8 \pm 2.3$ & $12.0 \pm 2.8$ \\
\hline
\end{tabular}


(Fig. 1). In the continuous culture Ch3 (Fig. 2C, high oxygen and high salinity), Sequence Type C dominated after only 1 to 2 volume changes in the culture. Differences in community composition of bacterial populations caused by salt have been shown for AOB, but also for other bacteria. Analysis of the whole bacterial community demonstrated high numbers of $\beta$-Proteobacteria in freshwater environments, but this group was almost absent in marine systems (Methé et al. 1998, Nold \& Zwart 1998, Glöckner et al. 1999). $\alpha$ - and $\gamma$-Proteobacteria were found in both systems, but they are affiliated with clusters consisting only of sequences from saline or non-saline environments (Glöckner et al. 2000). The AOB belonging to Sequence Type $\mathrm{C}$ are members of Nitrosomonas cluster $6 \mathrm{~b}$ (Stephen et al. 1998, Purkhold et al. 2000), and their closest cultured relatives are $N$. marina and $N$. aestuarii, both halophilic AOB (Pommerening-Röser et al. 1996). In the complete absence of salt, members of Nitrosomonas cluster 6a, a typical freshwater cluster consisting of halosensitive bacteria such as $N$. ureae and $N$. oligotropha, were enriched (PommereningRöser et al. 1996, Speksnijder et al. 1998, Stephen et al. 1998, Purkhold et al. 2000). In summary, in the presence of salt, relatives of already known halophilic AOB were enriched, and in its absence, members of a typical freshwater cluster developed.

Not all AOB detected by de Bie et al. (2001) were recovered in our experiments. Sequence Type A2 corresponding to Band 07-96.1 and Sequence Type C corresponding to Band 07-96.2 were found in both studies (Fig. 3). Sequence Type A1, which appeared in our starting and enrichment cultures, was not detected by de Bie et al. (2001). Sequence Type B (= Band 07-96.3) and D (= Band 07-96.4) disappeared in all enrichment cultures (Fig. 3; de Bie et al. 2001). Sequence Type B belongs to a group of AOB which are adapted to grow at very low ammonium concentrations. Members of this group were enriched at growthlimiting substrate concentrations of $5 \mu \mathrm{M}$ in continuous cultures (Bollmann \& Laanbroek 2001). We assume that these bacteria were out-competed in the beginning of the experiment, because the ammonium concentration was not low enough to be of real advantage to this group. Band 07-96.4 belongs to Sequence Type $\mathrm{D}$ and clustered in between Nitrosomonas clusters 5 and 6b (Fig. 3), both typical seawater clusters (Stephen et al. 1996, Purkhold et al. 2000).

\section{Influence of salt on AOB belonging to Sequence Type C}

In the absence of salt, AOB belonging to Sequence Type $\mathrm{C}$ had higher growth rates in the batch cultures and lower growth-limiting substrate concentrations in continuous cultures than they had in its presence (Fig. 1, Table 2). This observation indicates that the AOB belonging to Sequence Type C are halotolerant, but not halophilic as their closest relatives Nitrosomonas marina and $N$. aestuarii (Pommerening-Röser et al. 1996). Halotolerant bacteria are able to tolerate certain amounts of salt, but their activity decreased in the presence of salt. This observation is in contrast to the measurements of potential nitrification rates determined at different salinities in samples taken over a salinity gradient in the Schelde in 1977 (Somville 1984). These nitrification rates were highest at salinities close to the natural values at the place of collection. This discrepancy with our results could be due to methodological differences; Somville (1984) measured the $\mathrm{N}$-serve sensitive ${ }^{14} \mathrm{C}$ incorporation at initial ammonium concentrations of $10 \mathrm{mM}$ over a time period of $2 \mathrm{~h}$. We measured the growth rates as nitrite and nitrate production over a longer period with initial ammonium concentrations of $1 \mathrm{mM}$. Another possibility could be that different parts of the AOB community became active. Molecular analysis showed that in the brackish water different AOB were present (de Bie et al. 2001), so a more halophilic group could have been active in the short-term incubation of Somville (1984), whereas another, more halotolerant group may have grown in our long-term experiments.

\section{Influence of oxygen on the activity of the enriched AOB}

The continuous cultures Ch1 (low oxygen) and Ch2 (high oxygen) (Fig. 2A,B) did not show such a sharp and immediate selection for a sequence type as did Ch3. Over the first 5 volume changes in both continuous cultures, Sequence Types A1, A2 and C were growing in co-culture. After 1 volume change we increased the ammonium concentration in the reservoirs of both continuous cultures. The ammonium concentration in the growth vessel of $\mathrm{Ch} 2$ remained low, but increased in the vessel of Ch1, indicating that under the prevailing conditions not all ammonium could be oxidized. When the ammonium concentration in the culture vessel had accumulated up to $0.5 \mathrm{mM}$, we increased the oxygen partial pressure from $0.6 \%$ $\mathrm{O}_{2}$ to $1 \% \mathrm{O}_{2}$ and the ammonium was again completely oxidized to nitrite and nitrate. So the oxygen partial pressure had a major influence on the activity of bacteria, but not on the AOB community composition. A similar observation was made in soils and sediments along an oxygen gradient where $\mathrm{AOB}$ were able to adapt to lower oxygen availability (Bodelier et al. 1996), but the differences in the oxygen availability had no influence on the AOB community (Kowalchuk et al. 1998). 


\section{Natural water as basis of the medium}

The AOB from both sampling points grew better in their own natural water supplemented with ammonium compared to mineral medium (Fig. 1). This effect was even stronger when the continuous cultures were fed with mineral medium instead of water from the Schelde estuary supplemented with ammonium (results not shown). This positive effect of the water from the Schelde estuary could have different reasons. The water could contain a compound that is directly necessary for the activity and growth of the AOB, such as homoserine lactones (Batchelor et al. 1997), small organic compounds (Clark \& Schmidt 1967), or ions which are not provided in the trace element solution. It could be also a product directly produced by heterotrophic bacteria while metabolizing dissolved organic compounds in the different enrichment cultures, because the Schelde estuary contains high amounts of dissolved organic substances and has a high heterotrophic bacterial production (Goosen et al. 1997).

\section{Niche differentiation between culture and wall growth}

At the end of the experiments we also sampled the wall growth in all 3 continuous culture vessels and compared it with the culture. No difference was observed for Ch1 (low oxygen and low salt) and Ch3 (high oxygen and high salt). In both continuous cultures Sequence Type C was dominant at the end of the experiment. But in Ch2 we observed a niche differentiation between culture and wall. Sequence Type A1 was found in the culture, and Sequence Type $C$ on the wall (Table 2). Niche differentiation between attached and free-living cells occurs in AOB (Phillips et al. 1999) and marine bacteria (de Long et al. 1993). This differentiation could be due to physiological differences such as the ability to produce extracellular polymeric substances (Stehr et al. 1995).

\section{CONCLUSION}

In summary, batch and continuous culture experiments in combination with molecular methods show that salt, and not oxygen, is the regulating factor responsible for the observed population shift of the ammonia-oxidizing bacteria in the river Schelde.

Acknowledgements. This work was supported by a postdoctoral grant from the German Research Council (DFG; Bo15161/1) and by a grant from the Earth and Life Science Foundation (ALW), which is subsidized by the Netherlands
Organization for Scientific Research (NWO). We thank the crew of the RV 'Luctor' for their help with sampling, Guus Postema for technical support, Miranda Kamst-van Agterveld, Arjen Speksnijder, and Gabriel Zwart for their support with the molecular work, and Paul Bodelier for critical comments on the manuscript. This is publication no. 2979 of the Netherlands Institute of Ecology (NIOO-KNAW).

\section{LITERATURE CITED}

Anderson IC, Poth M, Homstead J, Burdige D (1993) A comparison of $\mathrm{NO}$ and $\mathrm{N}_{2} \mathrm{O}$ production by the autotrophic nitrifier Nitrosomonas europaea and the heterotrophic nitrifier Alcaligenes faecalis. Appl Environ Microbiol 59:3525-3533

Bano N, Hollibaugh JT (2000) Diversity and distribution of DNA sequences with affinity to ammonia-oxidizing bacteria of the $\mathrm{b}$ subdivision of the class Proteobacteria in the Arctic Ocean. Appl Environ Microbiol 66:1960-1969

Batchelor SE, Cooper M, Chhabra SR, Glover LA, Stewart GSAB, Williams P, Prosser JI (1997) Cell density-regulated recovery of starved biofilm populations of ammoniaoxidizing bacteria. Appl Environ Microbiol 63:2281-2286

Belser LW, Schmidt EL (1980) Growth and oxidation kinetics of three genera of ammonia oxidizing nitrifiers. FEMS Microbiol Lett 7:213-216

Bodelier PLE, Libochant JA, Blom CWPM, Laanbroek HJ (1996) Dynamics of nitrification and denitrification in rootoxygenated sediments and adaptations of ammoniaoxidizing bacteria to low oxygen or anoxic habitats. Appl Environ Microbiol 62:4100-4107

Bollmann A, Laanbroek HJ (2001) Continuous culture enrichments of ammonia-oxidizing bacteria at low ammonium concentrations. FEMS Microbiol Ecol 37:211-221

Clark C, Schmidt EL (1967) Growth response of Nitrosomonas europaea to amino acids. J Bacteriol 93:1302-1308

de Bie MJM, Speksnijder AGCL, Kowalchuk GA, Schuurman T, Zwart G, Stephen JR, Diekmann OE, Laanbroek HJ (2001) Shifts in the dominant populations of ammoniaoxidizing $\beta$-subclass Proteobacteria along the eutrophic Schelde estuary. Aquat Microb Ecol 23:225-236

de Long EF, Franks DG, Alldredge (1993) Phylogenetic diversity of aggregate-attached vs. free-living marine bacterial assemblages. Limnol Oceanogr 38:924-934

de Rijk P, de Wachter R (1993) DCSE v2.54, an interactive tool for sequence alignment and secondary structure research. Comput Appl Biosci 9:735-740

Felsenstein J (1993) PHYLIP (Phylogeny Inference Package) version 3.5c. Department of Genetics, University of Washington, Seattle

Glöckner FO, Fuchs BM, Amann R (1999) Bacterioplankton compositions of lakes and oceans: a first comparison based on fluorescence in situ hybridization. Appl Environ Microbiol 65:3721-3726

Glöckner FO, Zaichikov E, Belkova N, Denissova L, Pernthaler J, Pernthaler A, Amann R (2000) Comparative 16S rRNA analysis of lake bacterioplankton reveals globally distributed phylogenetic clusters including an abundant group of Actinobacteria. Appl Environ Microbiol 66:5053-5065

Goosen NK, van Rijswijk P, Kromkamp J, Peene J (1997) Regulation of annual variation in heterotrophic bacterial production in the Schelde estuary (SW Netherlands). Aquat Microb Ecol 12:223-232

Jukes TH,Cantor CR (1969) Evolution of protein molecules. In: Munro HN (ed) Mammalian protein metabolism, Vol 3. Academic Press, New York, p 21-132 
Kandeler E, Gerber H (1988) Short-term assay of soil urease activity using colorimetric determination of ammonium. Biol Fertil Soils 6:68-72

Keeney DR, Nelson DW (1982) Nitrogen-inorganic forms. In: Page AL (ed) Methods of soil analysis. Part 2. American Society of Agron, Madison, WI, p 643-693

Kowalchuk GA, Stephen JR, De Boer W, Prosser JI, Embley TM, Woldendorp JW (1997) Analysis of ammoniaoxidizing bacteria of the $\beta$-subdivision of the class Proteobacteria in coastal sand dunes by denaturing gradient gel electrophoresis and sequencing of PCR-amplified 16S ribosomal DNA fragments. Appl Environ Microbiol 63:1489-1497

Kowalchuk GA, Bodelier PLE, Heilig GHJ, Stephen JR, Laanbroek HJ (1998) Community analysis of ammoniaoxidising bacteria, in relation to oxygen availability in soils and root-oxygenated sediments, using PCR, DGGE and oligonucleotide probe hybridisation. FEMS Microbiol Ecol 27:339-350

Methé BA, Hiorns WD, Zehr JP (1998) Contrasts between marine and freshwater bacterial community composition: analyses of communities in Lake George and six other Adirondack lakes. Limnol Oceanogr 43:368-374

Muyzer G, de Waal EC, Uitterlinden AG (1993) Profiling of complex microbial populations by denaturing gradient gel electrophoresis analysis of polymerase chain reactionamplified genes coding for 16S rRNA. Appl Environ Microbiol 59:695-700

Nold SC, Zwart G (1998) Patterns and governing forces in aquatic microbial communities. Aquat Ecol 32:17-35

Oren A (1999) Bioenergetic aspects of halophilism. Microbiol Mol Biol Rev 63:334-348

Phillips CJ, Smith Z, Embley TM, Prosser JI (1999) Phylogenetic differences between particle associated and planktonic ammonia-oxidizing bacteria of the $\beta$ subdivision of the class Proteobacteria in the northwestern mediterranean sea. Appl Environ Microbiol 65:779-786

Pommerening-Röser A, Rath G, Koops HP (1996) Phylogenetic diversity within the genus Nitrosomonas. Syst Appl Microbiol 19:344-351

Poth M (1986) Dinitrogen production from nitrite by a Nitrosomonas isolate. Appl Environ Microbiol 52:957-959

Poth M, Focht DD (1985) 15N kinetic analysis of $\mathrm{N}_{2} \mathrm{O}$ production by Nitrosomonas europaea: an examination of nitrifier denitrification. Appl Environ Microbiol 49:1134-1141

Purkhold U, Pommerening-Röser A, Juretschko S, Schmid MC, Koops HP, Wagner M (2000) Phylogeny of all recognized species of ammonia oxidizers based on comparative 16S rRNA and amoA sequence analysis: implications for molecular diversity surveys. Appl Environ Microbiol 66:5368-5382

Rysgaard S, Thastum P, Dalsgaard T, Christensen PB, Sloth NP (1999) Effects of salinity on $\mathrm{NH}_{4}^{+}$adsorption capacity, nitrification, and denitrification in Danish estuarine sediments. Estuaries 22:21-30

Editorial responsibility: Bess Ward,

Princeton, New Jersey, USA
Soetaert K, Herman PMJ (1995) Nitrogen dynamics in the Westerschelde estuary (SW Netherlands) estimated by means of the ecosystem model MOSES. Hydrobiologica 311:225-246

Somville M (1984) Use of nitrifying activity measurements for describing the effect of salinity on nitrification in the Scheldt estuary. Appl Environ Microbiol 47:424-426

Speksnijder AGCL, Kowalchuk GA, Roest K, Laanbroek HJ (1998) Recovery of a Nitrosomonas-like 16S rDNA sequence group from freshwater habitats. Syst Appl Microbiol 21:321-330

Stehr G, Zoerner S, Boettcher B. Koops HP (1995) Exopolymers: an ecological characteristic of a floc-attached, ammonia-oxidizing bacterium. Microb Ecol 30:115-126

Stephen JR, McCaig AE, Smith Z, Prosser JI, Embley TM (1996) Molecular diversity of soil and marine 16S rRNA gene sequences related to $\beta$-subgroup ammonia-oxidizing bacteria. Appl Environ Microbiol 62:4147-4154

Stephen JR, Kowalchuk GA, Bruns MAV, McCaig AE, Phillips CJ, Embley TM, Prosser JI (1998) Analysis of $\beta$-subgroup proteobacterial ammonia-oxidizer populations in soil by denaturing gradient gel electrophoresis analysis and hierarchical phylogenetic probing. Appl Environ Microbiol 64:2958-2965

van de Peer Y, de Wachter R (1994) TREECON for windows: a software package for the construction and drawing of evolutionary trees for the Microsoft windows environment. Comput Appl Biosci 10:569-570

van de Peer Y, Jansen J, de Rijk P, de Wachter R (1997) Database on the structure of small ribosomal subunit RNA. Nucleic Acids Res 24:111-116

Verhagen FJM, Laanbroek HJ (1991) Competition for ammonium between nitrifying and heterotrophic bacteria in dual energy-limited chemostats. Appl Environ Microbiol 57:3255-3263

Ward BB, Martino DP, Diaz MC, Joye SB (2000) Analysis of ammonia-oxidizing bacteria from hypersaline Mono Lake, California, on the basis of 16S rRNA sequences. Appl Environ Microbiol 66:2873-2881

Wise MG, McArthur JV, Shimkets LJ (1999) Methanotroph diversity in landfill soil: isolation of novel type I and type II methanotrophs whose presence was suggested by culture-independent 16S ribosomal DNA analysis. Appl Environ Microbiol 65:4887-4897

Wollast R (1988) The Scheldt estuary. In: Salomons W, Bayne BL, Duursma EK, Foerstner U (eds) Pollution of the North Sea, an assessment. Springer-Verlag, Berlin, p 183-193

Wood, PM (1987) Monooxygenase and free radical mechanisms for biological ammonia oxidation. In: Cole JA, Ferguson SJ (eds) The nitrogen and sulfur cycles. Cambridge University Press, Cambridge, p 219-243

Zwart G, Huismans R, van Agterveld MP, van de Peer Y and 6 others (1998) Divergent members of the bacterial division Verrucomicrobiales in a temperate freshwater lake. FEMS Microbiol Ecol 25:159-169

Submitted: September 21, 2001; Accepted: April 13, 2002

Proofs received from author(s): June 27, 2002 